\title{
THE INVERSE FORMS OF WOMEN'S ACTIVITIES IN THE TRADITIONAL UKRAINIAN CULTURE OF XVI-XIX CENTURIES
}

Purpose of Article. The purpose of the article is to research some inverse forms of women's activities in the traditional Ukrainian culture of XVI-XIX centuries. Methodology. The methodology of the article is based on the interdisciplinary approach, which includes the following methods: analysis, synthesis, historical-comparative, legal-comparative and culturological ones. Scientific Novelty. The scientific novelty of the article is the analysis of the inverse forms of the women activities in the traditional Ukrainian culture of XVI-XIX centuries such as the woman's right for matchmaking, the woman in army and woman in the urban corporative culture. Conclusions. Thus, in the Ukrainian culture, the women played various roles such as a mother, sister, and a homemaker Despite those positions, the historical and social circumstances made the woman to realize themselves in political, social and economic activities. Such processes were manifested in the inversion between male and female social roles. The most popular embodiments of it are the women's right of the matchmaking, women military service and craft professions.

Key words: social role, customary women's rights, traditional culture, sisterhood association, matchmaking.

Щербинін Сераій Вікторович, здобувач Національної академії керівних кадрів культури і мистецтв

Інверсійні форми діяльності жінок у традиційній культурі України XVI- XIX століття

Метою статті $\epsilon$ аналіз інверсійних форм діяльності жінок у традиційній українській культурі XVI-XIX ст. Методологія статті ґрунтується на міждисциплінарному підході, який включає в себе такі загальнонаукові методи як аналіз, синтез, історико-порівняльний, правово-порівняльний та культурологічний. Наукова новизна статті полягає аналізі таких інверсійних форм діяльності жінок у традиційній українській культурі XVI-XIX століть як право жінки свататися до чоловіків, жінка у військовій справі та жінка в міській корпоративній культурі. Висновки. Таким чином, протягом історії в українській культурі основними соціальними ролями жінок були матів, сестра та домогосподарка. Незважаючи на ці позиції, складні історичні та соціально-політичні обставини змусили жінку реалізувати себе у політичній, соціальній та економічній діяльності. Такі процеси виявлялися в інверсії між чоловічими і жіночими соціальними ролями, що втілилися у таких фрормах діяльності як право жінки свататися до чоловіків, жінка у військовій справі та жінки у ремісничій цеховій системі.

Ключові слова: соціальна роль, звичаєве право жінок, традиційна культура, посестринство, сватання.

Щербинин Сергей Викторович, соискатель Национальной академии руководящих кадров культуры и искусств Инверсионные формы деятельности женщин в традиционной культуре Украины XVI-XIX века

Целью статьи является анализ инверсионных форм деятельности женщин в традиционной украинской культуре XVI-XIX вB. Методология статьи основывается на междисциплинарном подходе, который включает в себя такие общенаучные методы как анализ, синтез, историко-сравнительный, право-сравнительный и культурологический. Научная новизна статьи заключается анализе таких инверсионных форм деятельности женщин в традиционной украинской культуре XVI-XIX веков как право женщины свататься к мужчинам, женщина в военном деле и женщина в городской корпоративной культуре. Выводы. Таким образом, на протяжении истории в украинской культуре основными социальными ролями женщин были матов, сестра и домохозяйка. Несмотря на эти позиции, сложные исторические и социально-политические обстоятельства заставили женщину реализовать себя в политической, социальной и экономической деятельности. Такие процессы оказывались в инверсии между мужскими и женскими социальными ролями, выразившиеся в таких формах деятельности как право женщины свататься к мужчинам, женщина в военном деле и женщины в ремесленной цеховой системе.

Ключевые слова: социальная роль, обычное право женщин, традиционная культура, посестринство, сватовства.

The actuality of research. The woman and her role in society occupy one of the most important places in the philosophical and culturological thought of the XX-XXI centuries. The equality of women, egalitarianism, and feminism are the subjects of the researches of sociologists, culturologists, philosophers and others. The Manifesto of Simone de Beauvoir «Le Deuxieme Sexe» [1] allowed us to rethink the reflection of the traditional and «male» roles of the women in society. In Ukrainian culture, a woman always had the right to vote and acted as an equal partner in her husband's family affairs. In spite of it, there were the manifestations of female activity with a «masculine character» in Ukrainian culture. That inversion of male and female roles determines the relevance of our research.

Analysis of researches and publications. The role of women in Ukrainian culture is the subject of various interdisciplinary researches in the humanitarian field. The famous figures of women in Ukrainian culture are analyzed in the works of V. Borysenko [11], I. Dziuba [4], Dovbyshenko M., Lugovyi O. [6], Cheban V. [13] and others. The concept of a woman in traditional Ukrainian culture was studied by Ponomariov A. [9], Kurochkin O. [5], Malanchuk-Rybak O. [7]. The female body is considered in the work of I. Ignatenko "The female body in the traditional culture of Ukrainians» [3]. Despite a large number of works, the issue of «masculine» roles of women in traditional culture remains little researched.

The purpose of the article is to research some inverse forms of women's activities in the traditional Ukrainian culture of XVI-XIX centuries.

Analyzing various scientific researches and historical documents, we can see the inversion between female and male social roles, when woman was a soldier, managers and had rather «male» rights. So, we can distinguish three forms of the unusual woman social position: a right of the matchmaking; the woman in army and woman in the urban corporative culture.

The first position deals with the process of matchmaking. Wedding is a phenomenon that includes a variety of ritual activities. Therefore, it is the complex of folk customs, etiquette, morals, social and legal concepts, family traditions, ancient beliefs. In addition, the institution of the wedding has the ethical and legal functions to regulate gender relations. The ritual of the matchmaking plays an important role in the traditional wedding ceremony. 
G. Beauplan, a famous traveler, describes the unusual Ukrainian custom of the matchmaking. A girl had the right to marry a fellow. The scientist stated that the custom was «incredible» and underlined that he had never the same one in the world. Analyzing the custom, G. Beauplan pays attention to the several following circumstances:

- The custom is the part of the cultivating culture;

- The custom must be followed;

- The girls, who make off to the people, usually do not get the refusal because due to the superstition. The Ukrainians believed that in such situation the man had to accept the proposition because the refusal led to the adversity to his family and the blood revenge [2, 62-63].

The important factor in the process of emancipation of a woman was the position of the Ukrainian church, whose prominent figures determined the ideology of the national liberation struggle. Analyzing the reasons of the changes in the traditional wedding ceremony in XVII century, M. Sumtsov in his work «Regarding the History of the South Russian Wedding Customs», remarks about «the invasion of the folk beliefs and ceremonies in the religious-ecclesiastical sphere». The struggle against foreign invaders mobilized the spiritual forces of Ukrainian society: «... The people's life developed and was marked by the extraordinary internal forces. It was a period of the powerful folk spiritual creativity, which was manifested in the various beautiful cycles of songs about the struggle against the Poles, in the development of the brother's associations, hospitals, Ostrog and Kyiv studios. That tendency involved also the clerics in the life of the ordinary peasant and made them use various folk Ukrainian and ancient elements in the religious sphere $[10,137] »$.

G. Beauplan researched also the other rudiments of the ancient marriage ceremonies. In this case, he describes the atypical ritual of the abducting a nobleman by a peasant, which was associated with the era of feudalism. According to G. Beauplan, although farmers were the serfs, they had the right or freedom to steal the noble virgins during the dance. The girls could be even the daughters of their landowner. So, the thief should be quick and had to run away with his prey into a neighboring wood and hide there for at least 24 hours. Only after that period, he could be forgiven. If the thief was caught earlier, he had to be killed. The kidnapped girl had the choice. If she wanted to marry him, he had to do it under the death penalty. If she did not want to marry him, the kidnapper was free $[2,64]$. G. Beauplan reports that this custom was allegedly in the Podilia region, whereas we do not have any facts that can prove these described custom.

I. Nechuj-Levytskyi, a Ukrainian writer and folklorist, tells about the custom of the girl's match and the refusal to marry, which shows some transformations of this custom. For example, at the end of the 9th century in the Voronezh region, the young man could refuse the girl's proposition by the threat to make suicide [5, 17]. So, we can say that these examples, taken from different ethnographic regions, indicate that the custom, described by G. Beauplan was rather widespread.

The growth of the role and importance of women in family relations led to the transformational changes in the system of marital traditions. A. Ponomariov explained that such transformations of the woman status of a woman had affected the changes in marriage and contributed to the creation of such forms of the marriage as the marriage by the matchmaking or agreement. That version of marriage was rather popular among many peoples and embodied the mutual consent of young people to marry and the obligatory parents blessing [12, 429]. The further development of marital relations was characterized by the limitation of the parent's authoritarian nature and the important role of the young couple. All of them created the prerequisites for the realization of love, which was the main family value $[12,429]$.

There were the special fairs of brides at the end of the 19th century in Yampil (Podolia region). On Tuesday at the holiday of Masnysia girls and boys went to the tavern, where the owner of the tavern «sold» the girls to the boys, praising his «good». At Easter, the «sold» girls had to give «buyers» a certain number of Easter eggs. The received money should be wasted on celebrating. The «Wier», a Polish magazine, reported those girls and fellows often got married. There is no information about the «fairs of brides» on the Left bank of the Dnieper. However, we could see many fairs in that region, which were the platform for young people to meet their love. M. Gogol highlighted such fair in the «Sorochintsi Fair».

The Russian patriarchal family differs from the Ukrainian one. The decisive word to marriage belonged to parents in Russian traditions. Premarital communication was limited. Moreover, young people could see themselves for the first time during the wedding ceremony. It led to the creation of such an institution as the matchmaker. The matchmakers had their own clients, who paid them for the good rich bride. Especially they were popular among the representatives of the merchant's estate, petty bureaucracy and bourgeoisie [5, 7]. We should note that the bride's disagreement to marry did not take into account her parents decided everything.

There was another meaning of the matchmaking in the Ukrainian rituals. Comparing the Ukrainian customs with Russians and many peoples of the East, the Caucasus, Southern Europe ones, we can see the active role of a woman in the identification of natural feelings and sympathies [5, 9]. So, the ancient custom of the girl's matchmaking and the right to refuse to marry in the form to present pumpkin show us that the girl was not the passive object of marital aspirations of a young man, moreover she was the equal actor of the marriage.

The characteristic feature of the Ukrainian traditional ritual of the matchmaking is the lack of a matchmaker. It can be explained by the well-developed communication among young people. The mutual consent was often manifested in the symbolic forms - sacred time and a sacred place. For example, it is the ritual of the mutual washing of a boy and girl near the cross on Epiphany, fixed at Lubny region at the end of the XIX century [5, 8-9].

The second role of a woman of the inverse character is the image of a woman-manager or woman-warrior in the legends and works of XVI-XVIIIth centuries. For example, Stanislav Orzechowski, an outstanding writer and philosopher, created the true hymn for a woman in the Renaissance style. Making the report at the Trento 
Ecumenical Council of the Catholic Church in 1547, he tried to advocate the idea of the right to marry for the Catholic priests: «... The basic essence of a human being depends on a woman who makes her husband happy that doubles his life. Therefore, she makes her husband free from all duties, rescues him, and protects him from dissolute luxury » $[8,127]$. At the same time, he emphasizes the role of women in the management field: «...Her husband and a woman take part in the management. According to the wise men, it is considered to be the greatest happiness ... ». In S. Orzechowski's opinion, the women's spheres are house-holding, the upbringing of children, caring for a man. «... Nothing is happier for her husband than the one. She supports him throughout her life, the house falls, family collapses, doubtful offspring appear without her... » [8, 127].

Analyzing the work of the Ukrainian humanist, O. Malanchuk-Rybak states that S. Orzechowski's speech had a character of predominantly individual reflection and was far from the recognition in that society. In his work «Ideology and Social Practice of the Women's Movement in the Western Ukrainian Lands of the XIXth - the first third of the $X X$ century» she underlines that the idea of equality between men and women was too radical and revolutionary. However, the researcher determines that those considerations broke the medieval interpretation of a woman as a witch or sinful creature [7, 21]. In our opinion, the impact of S. Orzechowski is his formulation of the ideal of a woman, which was based on ethnic and national traditions. According to D. Nalyvaiko, there is a clear intensive Russ identity in S. Orzechowski's consciousness [4, 97]. His position influences on this attitude to women, which we can see in the text of his speech at the Council of Trent. We should remark that the wife of Kyiv Russ was not a slave of her husband, which was proved by the traditional customary-legal culture and the «Russ Truth (Ruska Pravda)». So, this conception of the female role had all features of the humanism, which was widespread in the XVI century in Europe. Whereas we could see another situation in the Moscow state. The famous literary document of that period was Domostroi. It sharply restricted women's rights, established a system of her rules in family life. According to them, the woman should be completely isolated from public life and management.

Thus, we can see that the Italian women had the most considerable degree of freedom, the right to express their individuality among other nations in Western Europe during the Renaissance era. In Eastern Europe, the Ukrainian women had the same variety of freedoms and rights. However, the measure of her individual freedom, energy, and individuality did not deal with science and art. They concerned the activities of the public-political, business, legal, as well as, military areas.

Indeed, the civil rights of women, particularly the right for the possession, guaranteed by the Lithuanian Statutes, were wider than the same ones in Western Europe, where «any woman's hereditary property was seen as an opportunity to increase the profitability other families» [11, 14]. Generally, the Lithuanian Statutes absorbed the part of the Renaissance political and legal ideas and defended the women's property and personal rights. Describing the First Lithuanian Statute of 1528, N. Yakovenko lists up the following its Renaissance ideas:

- the concept of equal responsibility before the law of the ruler, subjects and government;

- the Institute of the oath of the officials included the Grand Duke;

- the protection of the interests of a private person by the Institute of advocacy, which was free for the needy;

- the principle of personal responsibility before the law;

- the detailed fixation of the property and personal rights of women;

- the tolerant attitude towards the representatives of various professions and ethnic groups [14, 173].

Antony I / J. Rolle /, a Polish historian, states in his essay "Ukrainian Women» that the traditional Ukrainian customary law included more women rights in comparison with the Lithuanian Statutes. He noted that in the border regions the woman enjoyed significantly more freedoms than in the central regions of Poland / 3, 268 /. An example of the embodiment of the principle of egalitarianism was the figure of Anna Borzobaguta-Krasenska, a noblewoman. She ruled the treasury of the Lutsk diocese, attacked the estates of the gentry', and even refused to obey the king's orders. When the general militia of the whole voivodship attacked her, that brave woman headed her guards, protected her city from the enemy's attacks and defeated their army [11, 35]. In our opinion, the confrontation between Anna Borzobaguta-Krasenska and the two Polish kings, Sigismund-Augustus and Stefan Batory, has the gender aspect. The struggle of Anna Krasenska is the manifestation of the freedom, character, and the individuality of the Ukrainian woman. The participation of Ukrainian noble women in hostilities, raids and the protection of their own homes and was the widespread phenomenon of that social life. Thus, there is the record, dated by 1584 in the active book of the Zhytomyr town government. It is devoted to Mylochna Ostapkova raid on the estate of Hniavash Strizhevskyi where he suffered considerable losses. Mylochna Ostapkova did it with her daughter Sofia [11, 84].

In addition to the militant figure Anna Borzobaguta-Krasenska, we can mention such women as Anna Mylska, Maria Golshanska, Princess Ruzhynska, and Zofiya Ezofova, who appeared in full knight armor for royal military service in 1565 [11, 34].

The figures of the Ukrainian Cossacks appeared along with the militant noblewoman, who defended the family treasure with arms in their hands. They with their husbands fought against the arbitrariness of the Polish authorities. For example, Varvara Motora, the wife of the Cossack centurion Semen Motora, took part in the uprising, headed Yakiv Ostryanyn, the Zaporozhian Hetman (1638). She showed her brave nature during the protection of the rebel camp on the river Sula, near Zhovtina. According to the legend, Yakiv Ostryanyn instructed Varvara Motora to shoot the leaders of the Polish troops. At the same time, six Cossacks who reloaded muskets and gave arrows accompanied the woman sniper. By the way, she had brilliant skills of shooting by firearms and bows [11, 35].

The Cossacks of the Right bank of the river Dnieper respected Feodosia Palyikha, the wife of the Fastiv Colonel Semen Paliyi. In his work of «Famous Women of Ukraine», O. Lugovyi states that F. Palyikha managed the regimental administration as well as took part in the various military campaigns and protected her native land 
from foreign invaders. Moreover, when Peter I exiled her husband to Siberia, she continued joining the Cossacks raids $[6,157]$. The other manifestations of the inverse woman role were the institution of the sisterhood and the right of the corporate heritage. Sisterhood institution is the social version of the brotherhood among Cossacks. It was widespread in Ukrainian towns as the form of social cooperation. There were three types of Sisterhood institutions:

1. One-immersion one is associated with the procedure of baptism. Parents, wishing to continue their brothers' relations through their children, baptized them in one font.

2. Ordinary is the kind of friendship among women and their cooperation in various field of social activities.

3. Godmother meant the collective election of the sisters by the process of christening. It happened only on Semyk - the Thursday before the Trinity holiday and on Peter's Day (July $12^{\text {th }}$ ) [9, $\left.1125-1126\right]$.

The Corporate identity was characteristic for the population of towns. The various social strata of the burghers united around their communities: unions, clubs, and workshops, with the inherent statutes, rights, and responsibilities for each of them. The main type of urban corporate associations were the craft ones. The potters, blacksmiths, doctors, traders, bricklayers had their communities, which functioned according to the rules. They were formed in accordance with the rules and approved by the supreme authority. The inner life of the association was based on the principles of the code of honor, which defined as the subordination of the younger elders and compliance with the rules of social justice. Those rule defended the rights of the workers as well as their widows. So, in case of the craftsman's death, the woman could occupy his place. We propose to your attention the following rules where we see the attitude to the widows:

1. If the artisan died, the head of the manufacturer took over all the costs, associated with his burial, the well-being of the family of the deceased materially and immaterially».

2. In order not to cease the tradition of the master, the experienced master had to teach the widow the professional skills to earn for living [9, 1119].

Scientific Novelty. The scientific novelty of the article is the analysis of the inverse forms of the women activities in the traditional Ukrainian culture of XVI-XIX centuries such as the woman's right for matchmaking, a woman in army and woman in the urban corporative culture. Conclusions. Thus, in the Ukrainian culture, the women played various roles such as a mother, sister, and a housewife. Despite those position, the historical and social-political circumstances made the woman to realize themselves in political, social and economic activities. Such processes were manifested in the inversion between male and female social roles. The most popular embodiments of it are the women's right of the matchmaking, women military service and craft professions.

\section{תimepamypa}

1.Бовуар де С. Друга стать: у двох томах. Книга 1. Київ : ОСНОВИ, 1994. 390 с.

2. Весілля: у 2 книгах. Кн. 1. Київ : Наукова думка, 1970. 452 с.

3. Ігнатенко І. Жіноче тіло у традиційній культурі українців. Київ: Дуліби, 2013. 228 с.

4. Історія України в особах: Литовсько-Польська доба. О. Дзюба, М. Довбишенко, О. Русина. Київ : Україна, 1997. 272 с.

5. Курочкін О. В. Українці в сім'ї європейській: Звичаї, обряди, свята. Київ: Бібліотека українця, 2004. 248 с.

6. Луговий О. Визначне жіноцтво України. Київ : Дніпро, 1994. 335 с.

7. Маланчук-Рибак О. Ідеологія та суспільна практика жіночого руху на західно-українських землях XIX - першої третини XX ст.: типологія та європейський культурно-історичний контекст: монографія. Чернівці : Книга - XXI, 2006. 500 с.

8. Оріховський С. Промова у справі закону про целібат. Українські гуманісти епохи Відродження. Ч. 1. Київ : Основи, 1995. С. 112-118.

9. Пономарьов А. П. Звичаєві норми громадського побуту. Історія української культури: у 5 томах. Книга 5. Українська культура другої половини XVII-XVIII століть. Київ : Наукова думка, 2003. С. 1117 - 1136.

10. Сумцов Н. К истории южнорусских свадебных обычаев. Киевская Старина. 1883. № 11. С. 127-129.

11. Українки в історії. За ред. В. Борисенко. Київ: Либідь, 2004. 328 с.

12. Українці: Історико-етнографічна монографрія: у 2-х кн. Кн. 1. Опішне, 1999. С. $409-431$.

13. Чебан В. O. Female images of Ukrainian woman in the works of illustrators, designers of books and magazines of the twentieth century. Вісник Національної академії керівних кадрів культури і мистецтв. 2018. № 3. С. 181-184.

14. Яковенко Н. Нарис історії середньовічної та ранньомодерної України. Київ : Критика, 2006. 584 с.

\section{References}

1. Beauvoir, S. (1994). Le Deuxieme Sexe: in two volumes. Volume 1. Kyiv: OSNOVY [in Ukrainian].

2. Wedding: in 2 books. Book. 1. (1970). Kyiv: Naukova Dumka [in Ukrainian].

3. Ignatenko, I. (2013). The Female Body in the Traditional Ukrainian Culture. Kyiv: Duliby [in Ukrainian].

4. Dzyuba, O., Dovbyshenko, M. \& Rusina O. (1997). History of Ukraine in Figures: Lithuanian-Polish Era. Kyiv: Ukraine [in Ukrainian].

5. Kurochkin, O. V. (2004). Ukrainians in the European Family: Manners, Ordinances, Holidays. Kyiv: Biblioteka Ukraintsya [in Ukrainian].

6. Lugovoi, O. (1994). The Distinguished Womanhood of Ukraine. Kyiv: Dnipro [in Ukrainian].

7. Malanchuk-Rybak, O. (2006). Ideology and Social Practice of the Women's Movement in the Western Ukrainian Lands of the XIXth - the

first third of the XX Century: typology and European cultural-historical context: monograph. Chernivtsi: Knyga - XXI [in Ukrainian].

8. Orekhovskyi, S. (1995). Speech on the Law of Celibacy. Ukrainian humanists of the Renaissance. Ch. 1. Kyiv: OSNOVY [in Ukrainian].

9. Ponomariov, A. P. (2003). The Customary Norms of Social Life. History of Ukrainian Culture: in 5 volumes. Volume 5. Ukrainian culture of the second half of the XVII-XVIII centuries. Kyiv: Naukova Dumka [in Ukrainian].

10. Sumtsov, N. (1883). On the History of South Russian Wedding Customs. Kievskay Staryna, No. 11, 127 - 129 [in Russian].

11. Borysenko, V. (ed.). (2004). Ukrainian Women in History. Kyiv: Lybid [in Ukrainian].

12. Ukrainians: Historical and Ethnographic Monograph: in 2 books. Book. 1. (1999). Opishne [in Ukrainian].

13. Cheban, V. O. (2018). Female Images of Ukrainian Woman in the Works of Illustrators, Designers of Books and Magazines of the Twentieth Century. Visnyk Natcionalnoi akademii kerivnykh kadriv kultury I mystectv, 3. 181-184 [in English].

14. Yakovenko, N. (2006). An Essay on the History of Medieval and Early Modern Ukraine. Kyiv: Krytyka [in Ukrainian]. 